\title{
Seismic swarm at Bransfield Basin, South Shetland Islands (Antarctica)
}

Leda Sánchez Bettucci ${ }^{1}$, Judith Loureiro Olivet ${ }^{1,2}$, Oscar Alberto Castro Artola ${ }^{3}$, Enrique Latorres ${ }^{1,4}$, Agustín Chanes ${ }^{1}$, Hernán Castro ${ }^{1,2}$, Martín Rodríguez ${ }^{1,2}$, Anahí Curbelo ${ }^{1,2}$, Damián Dell'Acqua ${ }^{1} .{ }^{1}$ Observatorio Geofísico del Uruguay. Facultad de Ciencias, UDELAR, ${ }^{2}$ Dirección Nacional de Minería y Geología, Ministerio de Industria Energía y Minería, ${ }^{3}$ Instituto de Investigación en Gestión de Riesgos y Cambio Climático. Centro de Monitoreo Vulcanológico y Sismológico de la Universidad de Ciencias y Artes de Chiapas. ${ }^{4}$ Universidad ORT.

Copyright 2021, SBGf - Sociedade Brasileira de Geofísica

This paper was prepared for presentation during the $17^{\text {th }}$ International Congress of the Brazilian Geophysical Society held in Rio de Janeiro, Brazil, $16-19$ August 2021.

Contents of this paper were reviewed by the Technical Committee of the $17^{\text {th }}$ International Congress of the Brazilian Geophysical Society and do not necessarily represent any position of the SBGf, its officers or members. Electronic reproduction or storage of any part of this paper for commercial purposes without the written consent of the Brazilian Geophysical Society is prohibited.

\begin{abstract}
A seismic swarm began on August 26, 2020 in the Bransfield Basin (South Shetland Islands-Antarctica). The King George Island is part of the South Shetland microplate situated in a complex tectonic context (to the North, East, West and South the South Shetland - Phoenix subduction zone, the Shackleton and Hero fracture zones, and the Brasfield back-arc basin are located). The Observatorio Geofísico del Uruguay has installed since March 2020 a seismological station (raspberry-shake 3D, AM.R4DE2) at the Artigas Antarctic Scientific Base (BCAA: 62.1802, -58.8853). The station was operating from March 8 to 13 and began recording again on August 8, 2020. The only months that have been able to be reviewed in their entirety have been August 2020 and January 2021. Additionally, due to the existence of some gaps (time without data), not all earthquakes were recorded in the seismograms, this could be the product of instrumental errors or data transmission system lapses through the internet. The seismic records were parameterized by their waveform and S-P arrival times. The seismic source distance was calculated according to the arrival times of the $\mathrm{P}$ and $\mathrm{S}$ phases using the Bransfield basin velocity model proposed by Robertson et al. (2003) recalculated in Loureiro Olivet et al. (2021 under review) who obtained a value of $6.11 \mathrm{~km} / \mathrm{s}$ for $\mathrm{Vp}$ and 6.55 for the Omori coefficient. The epicentral distance and depth were calculated considering the angle of incidence of the $\mathrm{P}$ wave obtained from particle motion analysis and the hypocentral distance. The angle of incidence was calculated using the formula of Wiechert (1907). For the localization we use single station observations which require the calculation of the backazimuth for which the amplitudes of the first $P$ wave were considered. From this seismic swarm, 5652 events have been parameterized to date, of which 815 present $\mathrm{ML} \geq 4$. From the 5652 events reviewed manually, 757 correspond to August, 3119 to September, 222 to October, 569 to November, 290 to December, 206 to January, 152 to February, 27 to March, 268 to April and 42 to May. From the 815 earthquakes of ML $\geq 4,49$ correspond to August, 217 to September, 78 to October, 218 to November, 47 to December, 65 to January, 33 to February, 8 to March, 85 to April and 15 to May. The average depth obtained is approximately $11 \mathrm{~km}$ while the epicentral distance is ca. 25 $\mathrm{km}$. According to the epicentral location, most of the seismic events occur in the upper plate being related to the movement of active normal faults of ENE attitude that limit the Bransfield basin. In addition, epicenters near surface faults with NNW directions have been recorded within King George Island and near the NNW Artigas fault, which limits two blocks of different cortical thickness within the South Shetland microplate. Also, some events have been located near the caldera of the Orca volcano in the Bransfield basin.
\end{abstract}

\section{References}

Robertson, M.S.D.; Wiens, D.A.; Shore, P.J.; Vera, E.; Dorman, L.M. (2003). Seismicity and tectonics of the South Shetland Islands and Bransfield Strait from a regional broadband seismograph deployment. Journal of Geophysical Research 108 (B10): 2461-2473.

Loureiro Olivet, J., Leda Sánchez Bettucci, L., Castro Artola, O.A., Castro, H., Rodriguez, M., Latorres, E. (2021). A Seismic Swarm at the Bransfield Rift, Antarctica. Journal of South American Earth Sciences (under review). 
Wiechert, E., 1907. Über Erdbebenwellen. Theoretisches über die Ausbreitung der Erdbebenwellen. Nachrichten von der Königlichen Gesellschaft der Wissenschaften zu Göttingen, Mathematisch-physikalische Klasse, 413529. 